\title{
Contaminant characterization in wetland media surrounding a pulp mill industrial effluent treatment facility
}

\author{
Meaghan E. Quanz (1D) Tony R. Walker • Ken Oakes • Rob Willis
}

Received: 24 February 2020/ Accepted: 17 December 2020/Published online: 10 January 2021

(C) The Author(s) 2021

\begin{abstract}
Three media (sediment, surface water, and dragonfly larvae tissue) were collected from wetlands surrounding an industrial effluent treatment facility prior to closure. Samples were analyzed for metals, total mercury, and polychlorinated dibenzo- $p$-dioxins/ polychlorinated dibenzofurans (PCDD/PCDF) concentrations. Sediment and surface water concentrations were compared to provincial and federal guidelines, as well as reference wetland concentrations. Exceedances of arsenic, cadmium, chromium, copper, zinc, and PCDD/PCDF guidelines were found in deeper areas of wetlands historically contaminated from effluent, as well as wetlands exposed to current effluent inputs. Composite Libellulidae samples were collected from wetlands, and comparisons were made to reference tissue concentrations $+20 \%$. Elevated $\mathrm{As}, \mathrm{Cu}$ and $\mathrm{Pb}$ tissue concentrations were measured at two site wetlands, but total mercury (THg) and PCDD/
\end{abstract}

Supplementary Information The online version of this article (https://doi.org/10.1007/s11273-020-09779-0) contains supplementary material, which is available to authorized users.

M. E. Quanz $(\bowtie) \cdot$ T. R. Walker

School for Resource and Environmental Studies,

Dalhousie University, Halifax, NS B3H 4R2, Canada

e-mail: meaghan.quanz@dal.ca

K. Oakes

Cape Breton University, Sydney, NS B1M 1A2, Canada

R. Willis

Dillon Consulting Limited, Halifax, NS B3S 1B1, Canada
PCDF reference tissue concentrations were higher than wetlands near the effluent treatment facility. Spearman rho tests identified a significant correlation between sediment and tissue $\mathrm{Pb}$ concentrations and between surface water and sediment $\mathrm{THg}$ concentrations. Results suggest relatively low ecological risk to macroinvertebrates within wetlands near the effluent treatment facility from current effluent inputs, and highlight strengths and weaknesses of federal and provincial guidelines.

Keywords Contaminant monitoring · Wetland ecological media $\cdot$ Industrial effluent $\cdot$ Multiple lines of evidence

\section{Introduction}

Wetland contamination from industrial activities has been an ongoing issue for decades (Moore 2008; Jones et al. 2009). Increasing appreciation for the value of wetlands has intensified research on negative effects of contaminants on wetlands (De Klerk et al. 2013; Nasirian and Irvine 2017). A Canadian industry with a high potential for contaminating aquatic environments is wood pulp production, attributable to the large volumes of wastewater produced (Pokhrel and Viraraghavan 2004; Munkittrick et al. 2013; Hoffman et al. 2017a, 2019). If pulp wastewater effluent is 
poorly managed, sufficient contaminants can enter aquatic environments to produce potential deleterious effects (Toczylowska-Maminska 2017). To reduce ecosystem impacts, Canadian pulp mill effluents are regulated under the Pulp and Paper Effluent Regulations (PPER) under the Fisheries Act (Fisheries Act 1985; PPER 1992; Roach and Walker 2017).

This study focuses on a pulp effluent treatment facility, known as the Boat Harbour Treatment Facility, in Boat Harbour, Pictou County, Nova Scotia. Historically, Boat Harbour was a tidal estuary located on Pictou Landing First Nation (PLFN) land historically referred to as A'se' $\mathrm{K}$ by the people of PLFN. PLFN community used A'se'K for recreational, spiritual and cultural practices (Pictou Landing Native Women's Group 2016; Hoffman et al. 2017a). In 1967, a pulp mill, located $4 \mathrm{~km}$ southwest of Boat Harbour, began operation and used Boat Harbour as a treatment facility for wastewater effluent (Fig. 1).

Originally, gravity sewers collected and transported raw effluent via a pipeline under East River prior to discharge into a ditch which then entered a natural wetland complex. Effluent flowed through the wetland into an earthen impoundment "Settling Pond 2" before being discharged into the Boat Harbour Treatment Facility and then the Northumberland Strait marine receiving environment. Raw pulp mill effluent contained many substances, including metals and polychlorinated dibenzo- $p$-dioxins and dibenzofurans (PCDD/PCDFs) (GHD 2018), which due to volume and contaminant concentration, were inadequately removed by natural treatment processes. Biota within the Boat Harbour Treatment Facility suffered mass fatalities and surrounding residents experienced strong odours (Pictou Landing Native Women's Group 2016). In 1971, effluent from a nearby chlor-alkali plant was also discharged into the Boat Harbour Treatment Facility, which continued until 1992 (Hoffman et al. 2017a).

Upgrades were made to the Boat Harbour Treatment Facility in 1972. Effluent was rerouted beyond East River into a lined ditch that discharged effluent into two $50,000 \mathrm{~m}^{3}$ settling basins, bypassing the original wetland discharge area. Following the settling basins, effluent was treated in an aeration settling basin (ASB) using aerobic microbial degradation and discharged into the stabilization lagoon (Boat Harbour) before release into Northumberland Strait (Alimohammadi et al. 2019). An impoundment was constructed to stop tidal incursions into the Boat Harbour Treatment Facility, altering the chemistry from saltwater to freshwater (Province of Nova Scotia 2018). Components of both treatment frameworks are outlined (Fig. 1). Fifty years of effluent discharge has deposited $>570,000 \mathrm{~m}^{3}$ of unconsolidated contaminated sediments into the Boat Harbour Treatment Facility (Alimohammadi et al. 2019, 2020; Dillon Consulting Limited 2019). In 2014, an effluent pipe leak led to the passing of the Boat Harbour Act (2015) which mandated closure of the Boat Harbour Treatment Facility by January 31, 2020, followed by remediation. Prior to remediation, characterization of contaminants is required (Hoffman et al. 2017a).

Despite a plethora of studies assessing contaminants in sediments, surface water and select biota within the Boat Harbour Treatment Facility lagoon (see Hoffman et al. 2015, 2017a; Romo et al. 2019; Chaudhary et al. 2020a), scant research has addressed contaminants in wetlands surrounding the Boat Harbour Treatment Facility. In 2017, GHD (2018) undertook sampling in the former discharge wetlands in the Boat Harbour Treatment Facility for a Phase II Environmental Site Assessment (ESA). Sediment and surface water samples were collected, and several metal and PCDD/PCDF exceedances were found (GHD 2018). In 2019, contaminant concentrations were measured using diffuse gradient in thin film samplers in select wetlands around the Boat Harbour Treatment Facility (Chaudhary et al 2020b). In 2019, additional sampling was done for a Human Health and Environmental Risk Assessment (HHERA), including sediment, surface water and biological media (GHD 2019). This study augments contaminant characterization initiated by GHD using multiple lines of evidence (LOE) in former discharge wetlands, and other wetlands surrounding the Boat Harbour Treatment Facility.

\section{Materials and methods}

Location of sample sites

Twenty-five wetlands were identified surrounding the Boat Harbour Treatment Facility $(527,090$ E, $5,056,643 \mathrm{~N}$ ), covering approximately 86.24 ha (WSP 2018). Wetlands were evaluated using desktop reviews of the Nova Scotia Wetland Vegetation and 


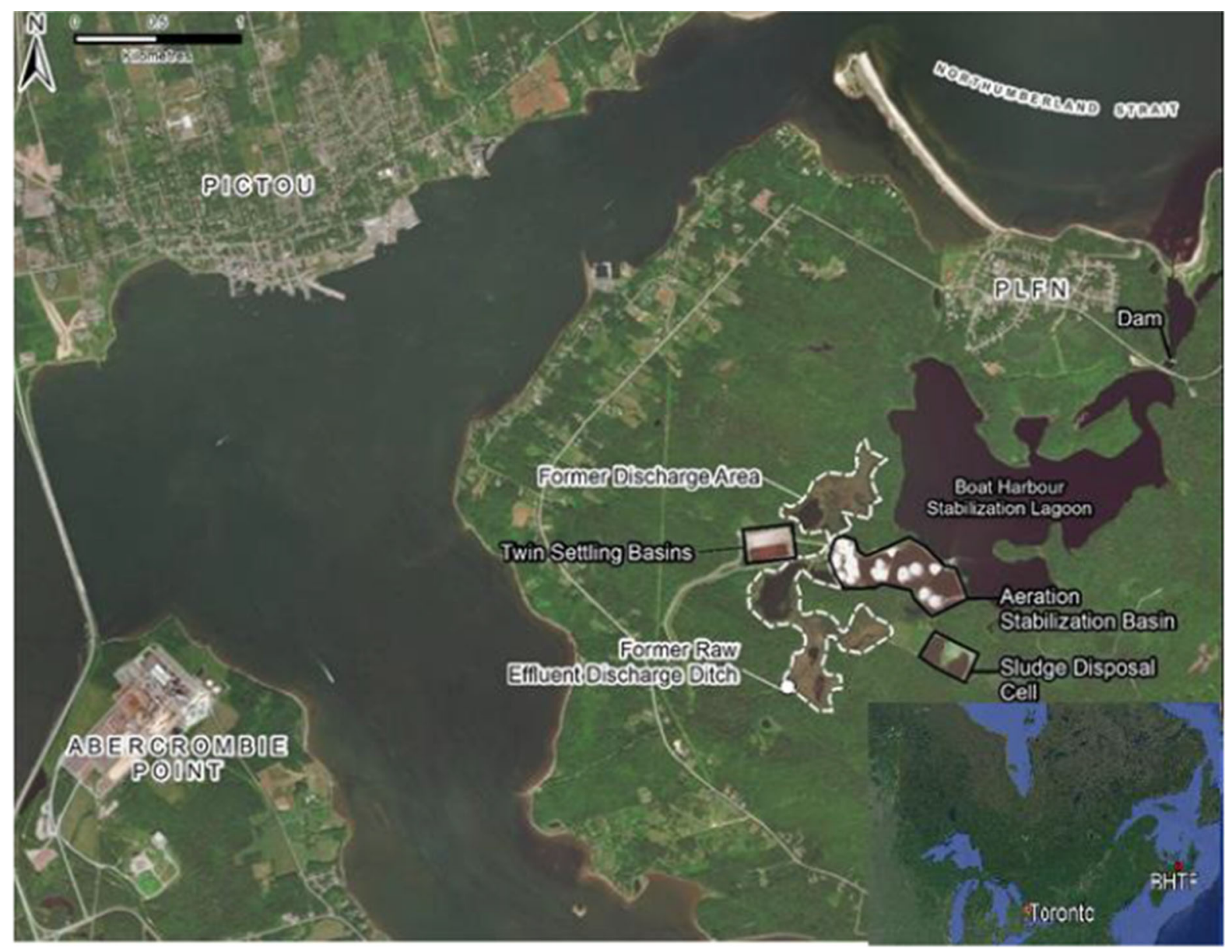

Fig. 1 Location of the Boat Harbour Treatment Facility in relation to Abercrombie Point, Pictou Landing First Nation, Pictou and Northumberland Strait. Components of the early

Classification Inventory, and field studies identifying hydrophytic vegetation, hydric soils and wetland hydrology. Wetlands were classified as either marsh (3), swamp (10), marsh-swamp complexes (11) or marsh-swamp marsh complexes (1) (WSP 2018).

Five wetlands surrounding the Boat Harbour Treatment Facility were selected as representative for investigation in this study, along with two far-field reference wetlands (Fig. 2). Two wetlands (WL1, WL2) were chosen based on the direct discharge point from 1967 to 1972. These wetlands were considered a priori highly contaminated and are herein referred to as heavily contaminated wetlands. Three wetlands (WL3, WL4, WL5) located around the Boat Harbour Treatment Facility were chosen based on comparable wetland type to WL1 and WL2 as well as accessibility. treatment framework (1967-1972) and the upgraded treatment framework (1972-present). [Map produced in ArcGIS®]

WL4 was selected due to its proximity to the sludge disposal cell. These wetlands were considered a priori moderately contaminated, due to connectivity to the Boat Harbour Treatment Facility and being currently exposed to effluent and are herein referred to as moderately contaminated wetlands. Two reference wetlands (REF1, REF2) were chosen using the Provincial Landscape Viewer based on similarity in size and wetland type to the Boat Harbour Treatment Facility wetlands (Nova Scotia Department of Natural Resources 2015) and are herein referred to as referenced wetlands. 


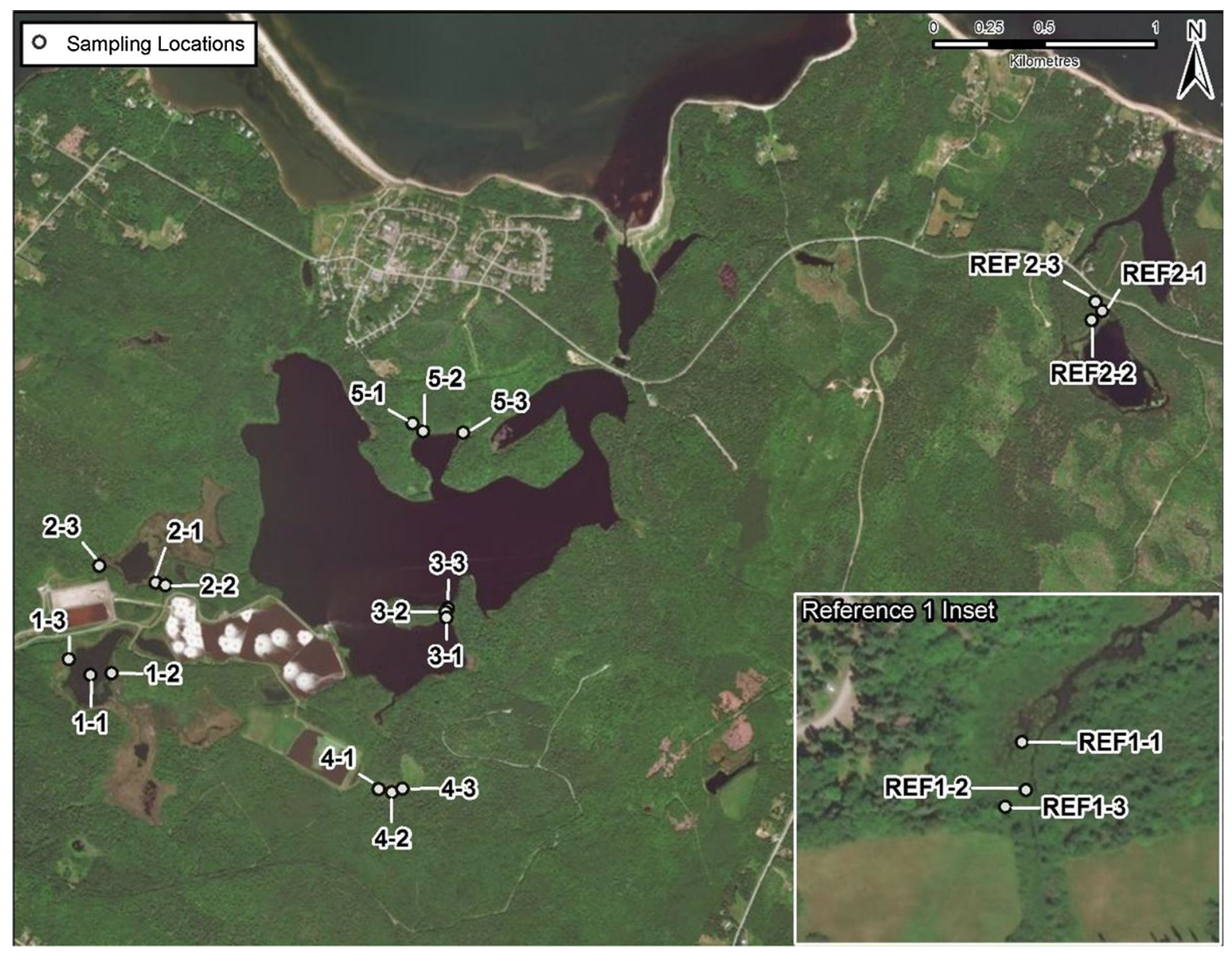

Fig. 2 Individual sampling stations for sediment and surface water samples [Map produced in ArcGIS ${ }^{\circledR}$ ]

Sediment sampling and analysis

Sampling occurred from July 23 to 27 , 2018. Triplicate sediment samples from each wetland were collected using a grade 316 stainless steel Petite Ponar Grab sampler $\left(152 \times 152 \mathrm{~mm}\right.$; Wilco $\left.{ }^{\circledR}\right)$ from the 0 to $10 \mathrm{~cm}$ horizon (Fig. 2) where previous studies found contamination to be concentrated (GHD 2018). A subsample from the grab was thoroughly mixed using a stainless-steel spoon, which was pre-washed in wetland surface water, and then transferred to individual clean glass jars $(250 \mathrm{~mL}$ jars for metals, $\mathrm{Hg}$ and PCDD/PCDF, and $120 \mathrm{~mL}$ jars for total organic carbon [TOC]). Samples were kept on ice during transport and stored in a $4{ }^{\circ} \mathrm{C}$ refrigerator prior to lab delivery. The grab was thoroughly rinsed in wetland surface water between sampling locations.
To assess variations in sediment contamination spatially and between vertical surface water columns, three sediment samples were collected from three water column depths [e.g. one from: shallow $(<50 \mathrm{~cm}) ;$ medium $(50-150 \mathrm{~cm}) ;$ and deep $(>150 \mathrm{~cm})$ ] at each wetland. Samples from REF2 were not collected due to equipment failure. Samples for PCDD/PCDF were only collected from one heavily contaminated wetland, one moderately contaminated wetland, and one reference wetland.

Samples were analyzed by AGAT Laboratories (Canadian Association for Laboratory Accreditation certified) for total organic carbon (TOC), 25 metals and PCDD/PCDFs. Only 7 metals (As, Cd, Cr, Cu, Pb, $\mathrm{THg}, \mathrm{Zn}$ ) are presented herein based on exceedances of SQGs in Boat Harbour Treatment Facility sediments in previous studies (Hoffman et al. 2017a, b). Sediment analysis for metals followed the USEPA 
Table 1 Spearman rho correlation values between sediment, surface water and tissue. I.D. marks relationships that could not be calculated due to identical concentrations

\begin{tabular}{lclllllll}
\hline COPC & As & $\mathrm{Cd}$ & $\mathrm{Cr}$ & $\mathrm{Cu}$ & $\mathrm{Pb}$ & $\mathrm{Hg}$ & $\mathrm{Zn}$ & $\mathrm{PCDD} / \mathrm{PCDF}$ \\
\hline Sediment and surface water & 0.21 & 0.37 & -0.20 & 0.33 & 0.31 & $0.54^{*}$ & 0.33 & - \\
Sediment and tissue & -0.11 & I.D & I.D & 0.00 & $-0.95^{*}$ & -1.0 & -0.78 & -0.50 \\
Surface water and tissue & 0.82 & I.D & I.D & 0.24 & -0.21 & I.D & 0.78 & - \\
\hline
\end{tabular}

Asterisk (*) represent $p<0.05$

method for acid digestion of sediments, sludges and soils prior to using inductively coupled plasma mass spectrometry (ICP-MS) following USEPA SW 846 6020A/3050B (USEPA 1996,1998) \& SM 3125 (Standard Methods for the Examination of Water and Wastewater 2017a). Metal detection limits (DLs) were $1(\mathrm{As}), 0.3(\mathrm{Cd}), 2(\mathrm{Cr}), 2(\mathrm{Cu}), 0.5(\mathrm{~Pb})$ and 5 (Zn) $\mathrm{mg} / \mathrm{kg}$, respectively. TOC analysis followed the MA. 405-C 1.1 titrage method (Center of Expertise in Environmental Analysis of Quebec 2014) and had a DL of $0.3 \%$. Total mercury (THg) analysis was based on the cold vapour (CA/VV) method from 245.5 (USEPA n.d.) and SM 3112B (Standard Methods for the Examination of Water and Wastewater 2017b) with a DL of $0.05 \mathrm{mg} / \mathrm{kg}$. PCDD/PCDF analysis followed the MA. 400- DF 1.0 method (Center of Expertise in Environmental Analysis of Quebec 2014) and the USEPA 1613 method using high resolution mass spectrometry (HRMS) (USEPA 1994b). DLs ranged from 0.6 to $100 \mathrm{ng} / \mathrm{kg}$. Mean values $( \pm \mathrm{SE})$ are reported throughout.

\section{Surface water sampling and analysis}

Triplicate surface water samples were collected immediately prior to sediment sampling at the same location to avoid sediments entering the sample (Fig. 2). Samples were collected in clean $250 \mathrm{~mL}$ plastic tubes containing nitric acid as a preservative. Samples were placed on ice during transport and transferred to a $4{ }^{\circ} \mathrm{C}$ refrigerator for short term storage. Within 1 week of collection, samples were transported to AGAT Laboratories (Canadian Association for Laboratory Accreditation certified) for analysis of 25 metals. However only seven metals (As, Cd, $\mathrm{Cr}, \mathrm{Cu}, \mathrm{Pb}, \mathrm{THg}, \mathrm{Zn}$ ) are discussed herein, as these exceeded guidelines as reported in previous studies (e.g. Hoffman et al. 2017a). Results of all 25 metals are attached in S1. Surface water analysis of metals followed a modified method from SM 3125/SM3030B/SM 3030D using ICP-MS (Standard Methods for the Examination of Water and Wastewater 2017a,2017c). DLs were 2 (As), 0.09 (Cd), 1 (Cr), $1(\mathrm{Cu}), 0.5(\mathrm{~Pb})$ and $5(\mathrm{Zn}) \mu \mathrm{g} / \mathrm{L}$, respectively. $\mathrm{THg}$ was analyzed using the SM 3112B method (Standard Methods for the Examination of Water and Wastewater 2017b) with a DL of $0.026 \mu \mathrm{g} / \mathrm{L}$. Mean values $( \pm \mathrm{SE})$ are reported throughout.

Tissue sampling and analysis

Odonata (dragonflies and damselflies) are frequently sampled for contaminants such as $\mathrm{Cd}, \mathrm{Cr}, \mathrm{Hg}$ and methyl-mercury (Me-Hg) (Buckland-Nicks 2011; Azam et al. 2015; Armellin et al. 2017; LeBlanc 2019). Odonata are important in aquatic systems, serving both as key predators and prey for other aquatic organisms, ubiquitous, relatively easy to collect, and larvae can exist for many years (Tollett et al. 2009; Jeremiason et al. 2016). During an earlier sampling event for a separate study, it was found that Odonata larvae were present in all wetlands in this study. Due to differences in body forms and habitat uses between Odonata families and genera (Fletcher et al. 2017), the family Libellulidae was solely selected for sampling and were collected using a triangular dip net. Following sweeps through vegetated areas of wetlands, dip nets were emptied into a Fieldmaster ${ }^{\circledR} 35$ mesh, $500 \mu \mathrm{m}$ sieve where Libellulidae of similar size (three to four $\mathrm{cm}$ length) were selectively removed. The target species selected during the study design phase and the reconnaissance trip to the study site were not as uniformly available as expected during the sampling event. Due to this, a limited number of specimens were collected, and did not meet the laboratory required amount of tissue mass 
available for analysis. Therefore, where samples collected, they were consolidated into one composite sample per wetland. Adequate quantities of tissue were collected in each of the wetland contaminated designations for metals analysis of 25 metals. However only seven metals (As, $\mathrm{Cd}, \mathrm{Cr}, \mathrm{Cu}, \mathrm{Pb}, \mathrm{THg}, \mathrm{Zn}$ ) are discussed herein, as these exceeded guidelines as reported in previous studies (e.g. Hoffman et al. 2017a). Results of all 25 metals are included in S1. Adequate tissue amounts were collected in heavily contaminated and reference wetlands for $\mathrm{THg}$, and each of the wetland contaminated designations for PCDD/PCDF analysis. Organisms were identified in the field using standardized keys from Batzer et al. (1999). The entire organism was analyzed to estimate contaminant concentrations that would be available for Libellulidae predators.

Samples were stored in clean $250 \mathrm{~mL}$ glass jars and kept on ice during transport. Jars were transferred to a $4{ }^{\circ} \mathrm{C}$ refrigerator for short term storage. Within a week of collection, samples were transported to AGAT Laboratories for analysis of COPC similar to sediment and surface water samples. Metals in tissue were analyzed using a modified method from USEPA 200.8 (USEPA 1994a) and USEPA 3050 (USEPA 1996), and had DLs of $2 \mathrm{mg} / \mathrm{kg}$ (As), $0.3 \mathrm{mg} / \mathrm{kg}$ (Cd), $2 \mathrm{mg} /$ $\mathrm{kg}(\mathrm{Cr}), 2 \mathrm{mg} / \mathrm{kg}(\mathrm{Cu}), 0.4 \mathrm{mg} / \mathrm{kg}(\mathrm{Pb})$ and $5 \mathrm{mg} / \mathrm{kg}$ (Zn). THg analysis followed a modified USEPA 245.6 method (USEPA 1991) with a DL of $0.05 \mathrm{mg} / \mathrm{kg}$. PCDD/PCDF analysis followed MA. 400- DF 1.0 method (Center of Expertise in Environmental Analysis of Quebec 2013) and the USEPA 1613 method using high resolution mass spectrometry (HRMS) (USEPA 1994b) with DLs ranging from 2 to $900 \mathrm{ng} /$ $\mathrm{kg}$.

Typha spp. (cattails) were collected at each wetland, however, this tissue was not analyzed. This research followed a tiered approach, where the decision to incorporate tissue was made based on sediment and surface water exceedances found in previous sampling events, and therefore sampling tissue could begin to determine whether contaminants were being incorporated into the food web. Odonates were ultimately sampled as the tissue example because Typha spp. had already been sampled as part of a consultant study (GHD 2019), and this project aimed to add new research into the broader Boat Harbour project.
Statistical analysis

To validate parametric test assumptions of normal distribution and equal variance, formal normality tests were run in Minitab ${ }^{\circledR} 18.1$ (Minitab Inc. 2017) for sediment, surface water and tissue samples. Normality was tested for each contaminant using Ryan-Joiner (Yap and Sim 2011) while homogeneity of group variances was evaluated using Bartlett's Test at a significance level of 0.05 . Data meeting parametric assumptions were tested using one-way ANOVAs followed by Dunnett's post-hoc analyses. Data failing either parametric test were log-transformed and retested prior to one-way ANOVA. Any data which could not be analyzed parametrically following log transformations were analyzed using Kruskal-Wallis and pair-wise Mann-Whitney tests. Correlation between all three media and COPCs was assessed using Spearman rho correlation.

\section{Comparison with applicable guidelines}

Sediment and surface water concentrations were compared to applicable guidelines. As the Boat Harbour Treatment Facility is located in Nova Scotia, provincial Environmental Quality Standards (EQS) for sediment from Tier 1, Table 2 standards were used when available (Nova Scotia Environment 2013). Comparisons were also performed against Interim Sediment Quality Guidelines (ISQG) and Probable Effect Level (PEL) national guidelines from the Canadian Council of Ministers of the Environment (CCME) (CCME 1999, 2001,2003). Often these two sets of guidelines were identical. Sediment concentrations below ISQGs were considered uncontaminated while those between ISQGs and PELs were considered moderately contaminated and concentrations exceeding PELs were considered heavily contaminated. NSE Tier 1 EQS, Table 3 were used when available for surface water (Nova Scotia Minister of the Environment 2013), as was national Water Quality Guidelines (WQG) (CCME 1999, 2001, 2003, 2018). Guidelines that were used are outlined in the supplementary material (S1) along with the raw results. As with sediment, concentrations below guidelines were considered uncontaminated while concentrations that exceeded guidelines were considered moderately to severely contaminated, depending on the degree of guideline exceedance. Due to the insufficient 
Libellulidae tissue collected, statistical analysis was not possible, and guidelines do not exist for contaminant concentrations in Odonata tissue. Therefore, concentrations were compared against reference concentrations $+20 \%$, a common practice in ERAs (EC \& OMOE 2008; Walker et al. 2015).

\section{Results}

\section{Sediment concentrations}

Wetland sediments upon visual inspection were generally fine-grained and black-brown in colour. Sediments from shallow areas had more organic material (e.g. roots, decomposing plant matter) than deeper areas. Grain size analysis on six sediment samples from WL1 and WL2, completed as part of a Human Health and Environmental Risk Assessment (HHERA), identified sediment as a mix of primarily clay (mean 40\%), sand (mean 28.2\%), and silt (mean $28.0 \%$ ) (GHD 2019).

Sediment TOC varied across the study sites (Fig. 3). TOC was highest at WL1 and WL5 at $26.7 \%$ and $35.7 \%$, respectively, which were higher than mean REF1 TOC of $17.3 \%$. WL2, WL3 and WL4 had low TOC of $11.8 \%, 0.9 \%$ and $12.3 \%$, respectively. WL1 and WL5 TOC differed significantly from WL3 TOC $(p<0.001)$. TOC varied within each wetland; for example, the TOC WL2 sediment sample taken from the pelagic zone was $27.8 \%$, but samples taken from the littoral zone were much lower $(0.8 \%$ and $8.4 \%)$.

WL3 and WL4 exceeded the ISQG for As $(5.9 \mathrm{mg} /$ $\mathrm{kg}$ ), but were below guidelines for other COPCs (Fig. 3). WL1 exceeded ISQGs for As, Cd (0.6 mg/ $\mathrm{kg})$, Cr (37.3 mg/kg) and Zn (123 mg/kg) (Fig. 3). WL2 exceeded ISQGs for As, Cd, Cr, Cu (35.75 mg/ $\mathrm{kg}$ ) and $\mathrm{Zn}$ (Fig. 3). WL5 exceeded ISQGs for As, $\mathrm{Cu}$ and $\mathrm{Pb}$, and also exceeded NSE Tier 1 and PELs for $\mathrm{Cd}$ (3.5 mg/kg) and Zn (315 mg/kg) (Fig. 3). WL1 and WL2 were considered moderately contaminated for As, $\mathrm{Cd}, \mathrm{Cr}, \mathrm{Cu}$ and $\mathrm{Zn}$. WL3 and WL4 were considered moderately contaminated for As. WL5 was considered moderately contaminated for $\mathrm{As}, \mathrm{Cu}$ and $\mathrm{Pb}$, and more heavily contaminated for $\mathrm{Cd}$ and $\mathrm{Zn}$. WL1, WL2 and WL5 exceeded THg ISQG $(0.17 \mathrm{mg} /$ $\mathrm{kg}$ ) (Fig. 3). Sediment concentrations of As in WL2 and WL5 were significantly higher than REF1
( $p=0.01$ for both). Additionally, sediment concentrations of $\mathrm{Cd}$ and $\mathrm{Cu}$ in WL5 was significantly higher than REF1 ( $p=0.01$ and 0.007 respectively). Other wetlands were not significantly different $(p>0.05)$ from REF1 (Fig. 6). Some COPC concentrations varied within wetlands as well. For example, in WL2 $\mathrm{Cr}$ was more than three times greater in deeper water column sediment $(61.5 \mathrm{mg} / \mathrm{kg})$ than shallower sediment $(14 \mathrm{mg} / \mathrm{kg}$ and $17 \mathrm{mg} / \mathrm{kg})$. THg at all sites did not differ from the reference wetland $(p=0.052)$ (Fig. 3).

Mean PCDD/PCDF sediment concentrations in three wetlands (REF1, WL2 and WL4) exceeded the ISQGs $(0.85 \mathrm{ng} \mathrm{TEQ} / \mathrm{kg})$. WL2 exceeded the NSE Tier 1 and PEL guideline (21.5 ng TEQ/kg) (Fig. 4a). There were no significant differences between REF1 and other wetlands, likely due to the extreme outlier in WL2, which had the highest TEQ value of $594 \mathrm{ng}$ $\mathrm{TEQ} / \mathrm{kg}$, collected from the deepest surface water location (Fig. 4b). This was more than 200 times greater than the two other TEQ values $(2.0 \mathrm{ng} \mathrm{TEQ} / \mathrm{kg}$ and $2.6 \mathrm{ng} \mathrm{TEQ} / \mathrm{kg}$ ) from WL2.

\section{Surface water concentrations}

Surface water, which was transparent with a slight yellow-brown tinge, had metal concentrations which varied between sites. WL3 and WL5 generally exceeded guidelines (Fig. 5), where WL3 and WL5 exceeded CCME long-term exposure guidelines for $\mathrm{Cd}(0.09 \mu \mathrm{g} / \mathrm{L})$ and CCME Cr(VI)/NSE Cr guideline $(1 \mu \mathrm{g} / \mathrm{L})$, and CCME short-term exposure and NSE guidelines for $\mathrm{Zn}$ (37 and $30 \mu \mathrm{g} / \mathrm{L}$, respectively) (Fig. 5). Water hardness was unknown, so conservative CCME guidelines (adopted by NSE) for $\mathrm{Cu}(2 \mu \mathrm{g}$ / L) and $\mathrm{Pb}(1 \mu \mathrm{g} / \mathrm{L})$ were used. WL3 and WL5 exceeded both these guidelines (Fig. 5). REF1 also exceeded CCME long-term exposure guidelines for $\mathrm{Cr}(\mathrm{VI}), \mathrm{Zn}$ and $\mathrm{Pb}$. WL1, WL2 and REF2 only exceeded NSE Cd guidelines $(0.01 \mu \mathrm{g} / \mathrm{L})$.

Surface water concentrations of $\mathrm{Cr}$ and $\mathrm{Cu}$ were significantly higher than REF1 and REF2 $(p<0.001$ for both). Additionally, WL5 contained significantly higher surface water concentrations of Cd than REF1 and REF2 $(p<0.001)$. Arsenic concentrations in WL4 were significantly higher than REF1 and REF2 $(p<0.001)$ while REF1 $\mathrm{Pb}$ concentrations were significantly higher than REF2 $(p<0.001)$. WL3 and WL5 were also significantly higher than the REF2 

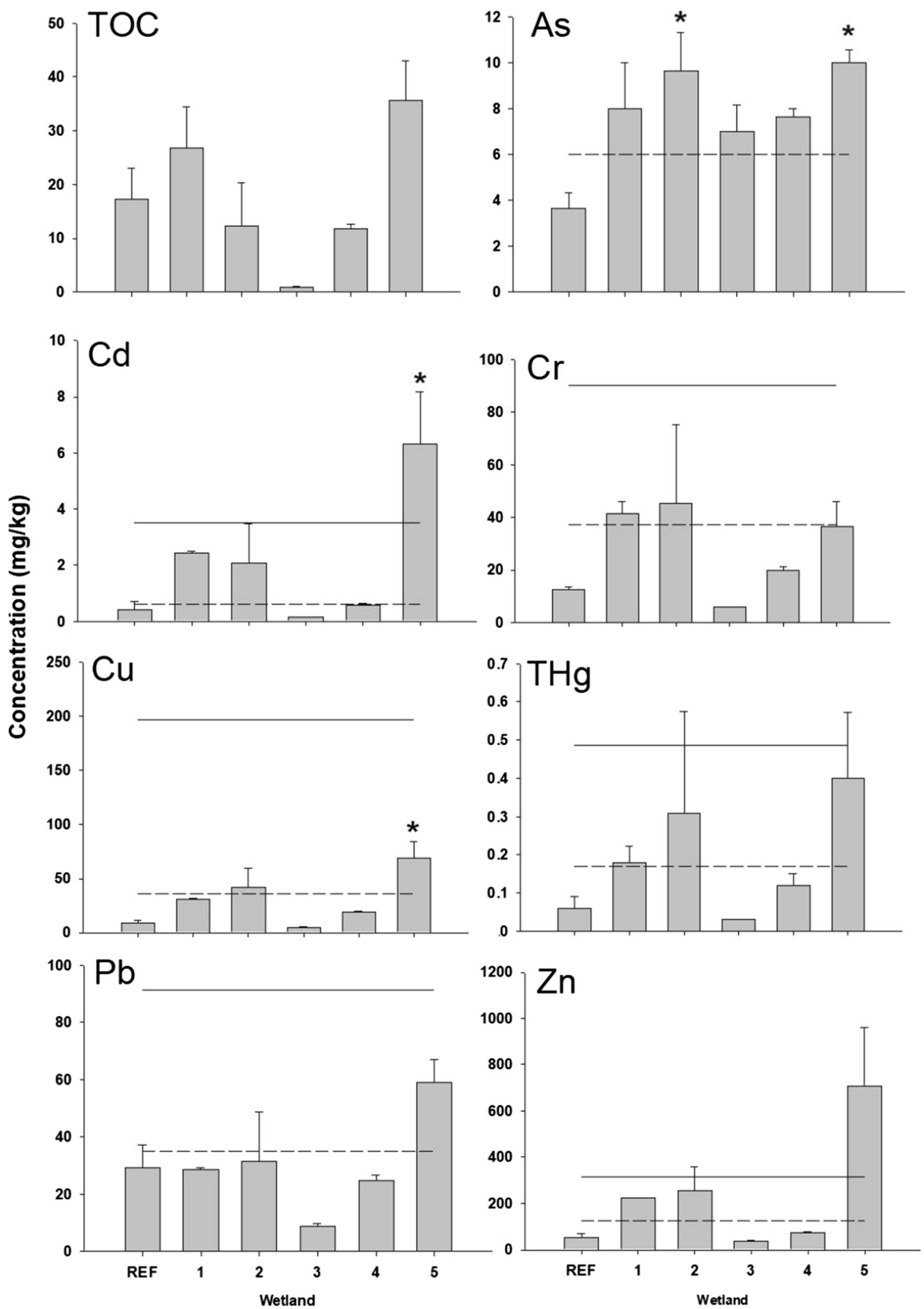
\Fig. 3 Mean sediment metal concentrations $(n=3, \pm \mathrm{SE})$. Asterisks $(*)$ identify concentrations significantly different than REF1 $(p<0.05)$. Dotted line identifies CCME ISQGs, and solid line identifies both the NSE Tier 1 guideline and the CCME PEL (CCME 2019; Nova Scotia Minister of the Environment 2013)

$\mathrm{Pb}$ level $(p<0.001)$. WL3 was significantly higher than the REF1 Pb level $(p<0.001)$. WL5 was the only site to contain $\mathrm{THg}$ concentrations above the detection limit and the CCME long-term exposure guideline (Fig. 5) and was significantly higher than REF1 and REF2 $(p<0.001)$.

\section{Tissue concentrations}

Comparison to reference values $+20 \%$ presented higher tissue concentrations of $\mathrm{As}, \mathrm{Cu}$ and $\mathrm{Pb}$ in WL1 and WL4 relative to the reference tissue (Fig. 6). All Cd and Cr values were below reportable DLs ( 0.3 and $2 \mathrm{mg} / \mathrm{kg}$, respectively). The highest concentration of $\mathrm{Zn}$ was measured in reference tissue. REF1 displayed the highest $\mathrm{THg}$ concentration (Fig. 6), as well as PCDD/PCDF concentrations (Fig. 6). For PCDD/PCDF, the REF1 tissue concentration was 6.5 times greater than WL4, and 42 times greater than WL2, which was the assumed highly contaminated wetland (Fig. 6).

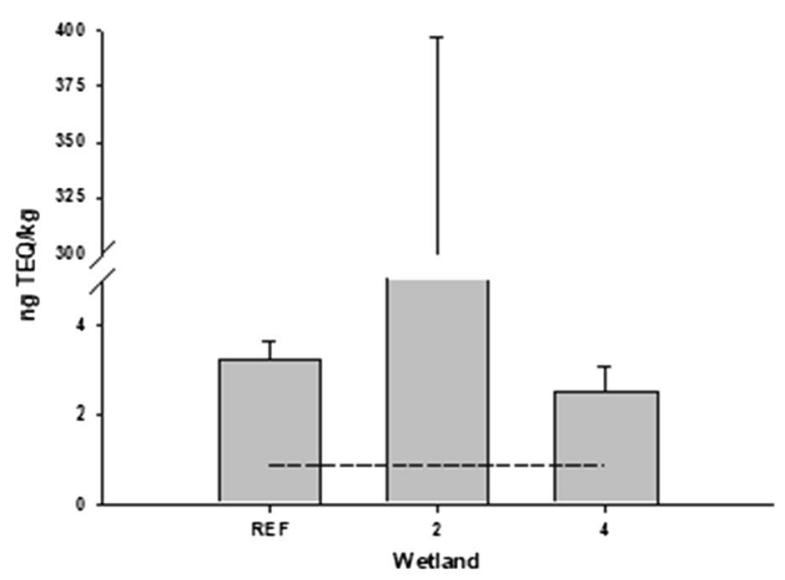

Fig. 4 Mean sediment PCDD/PCDF TEQ values $(n=3, \pm$ $\mathrm{SE})$. Dashed line represents the CCME ISQG (0.85 ng/kg). The solid line (not pictured here) represents the NSE Tier 1 and CCME PEL guideline of $21.5 \mathrm{ng} / \mathrm{kg}$ (CCME 2019; NSE 2013)
Relationship between media

Spearman rho correlation analysis between sediment, surface water and tissue revealed significant correlations between $\mathrm{Pb}$ in sediment and tissue and $\mathrm{Hg}$ in sediment and surface water (Table 1). Due to $\mathrm{Cd}$ and $\mathrm{Cr}$ tissue concentrations in all samples reading below detection limit, the correlation between sediment, surface water and tissue could not be calculated. Due to identical THg surface water concentrations in WL1, WL2 and REF1, the correlation between surface water and tissue could not be calculated. TOC has been shown to increase the amount of metal concentrations within sediment (Kalbitz and Wennrich 1998); therefore, correlation analysis between TOC and the COPC was also run (Table 2). Significant correlations were found between all COPC and sediment TOC, except for As and PCDD/PCDF.

\section{Discussion}

The goal of this study was to characterize contaminants in wetlands surrounding the Boat Harbour Treatment Facility to focus remediation efforts and to select appropriate remedial options (Eichinger and Walker 2020). To date, most studied had focused on sediment contaminant concentrations in Boat Harbour itself (i.e. Hoffman et al. 2017a, 2019), which has resulted in an estimated $577,000 \mathrm{~m}^{3}$ of contaminated

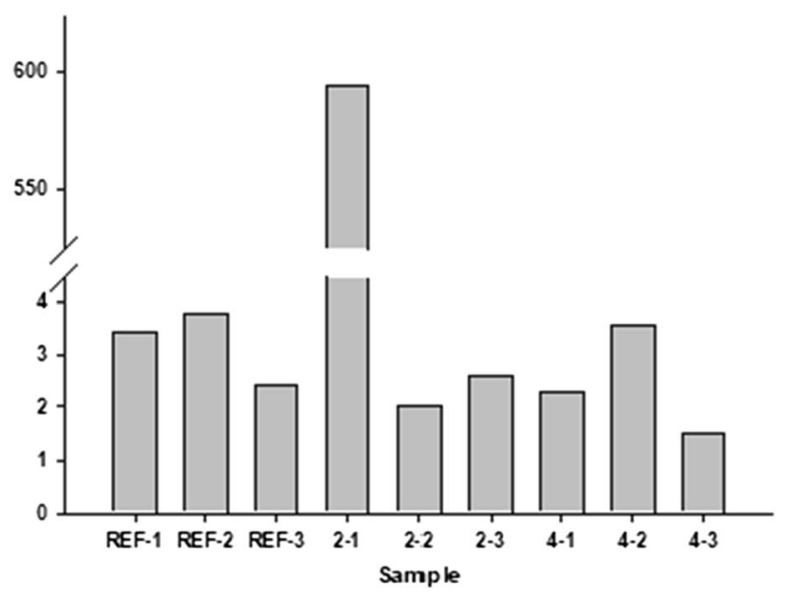

(a). Individual sediment PCDD/PCDF TEQ values measured in wetlands. Dashed line represents the CCME ISQG $(0.85 \mathrm{ng} / \mathrm{kg})$ (CCME 2019) (b) 


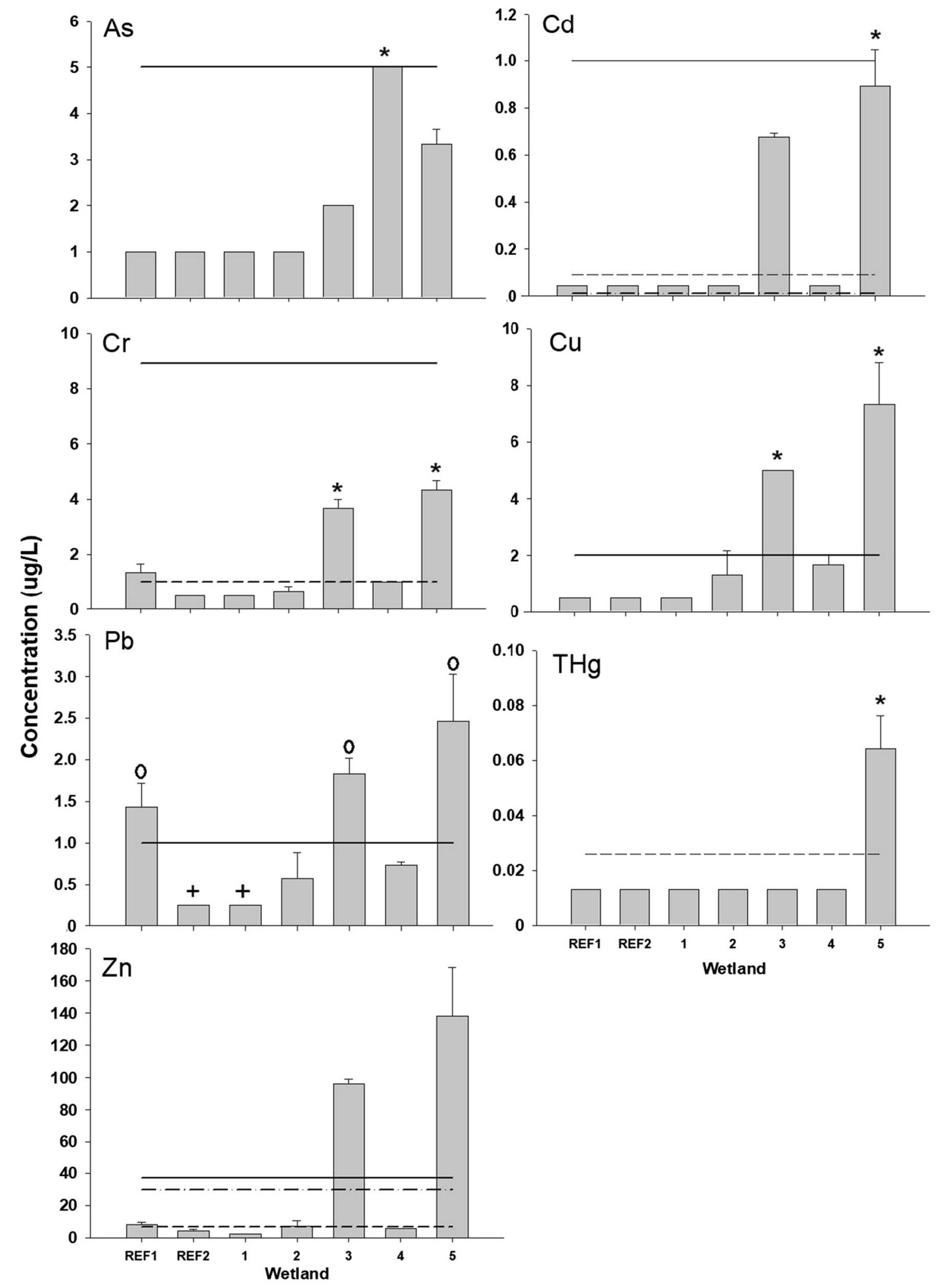


4 Fig. 5 Mean surface water metal concentrations $(n=3, \pm \mathrm{SE})$. Dotted line represents CCME long-term guideline values. Solid line represents CCME short-term guideline values. Dash-anddot line lines represent NSE Table 1, Tier 3 guidelines (CCME 2019; Nova Scotia Minister of the Environment 2013). In instances where CCME and NSE guidelines were the same, CCME guidelines were shown. Asterisk (*) identifies significant differences from both REF1 and REF2, cross $(+)$ identifies significant differences from REF1 and circle (0) identifies significant differences from REF2 $(p<0.05)$

sediment to be treated (Alimohammadi et al. 2020; Tackley et al. 2020). However, without proper characterization of sediments in wetlands surrounding the Boat Harbour Treatment Facility volumes of contaminated sediment to be treated could be approximately $1,244,000 \mathrm{~m}^{3}$, which could dramatically increase remediation costs (GHD 2018b; Eichinger and Walker 2020). To properly characterize sediments and other media in wetlands surrounding the Boat Harbour Treatment Facility contaminant concentrations were compared against applicable provincial and federal guidelines to inform remedial decisions. Both provincial and federal guidelines were used in this study as the Boat Harbour remediation project is currently undergoing a federal environmental assessment (Eichinger and Walker 2020; Government of Canada 2020) but is also subject to provincial regulatory oversight (Province of Nova Scotia 2020).

This study followed common risk assessment frameworks to assess contaminants in Boat Harbour Treatment Facility wetlands (Quanz et al. 2020) using a tiered approach where abiotic media is sampled initially and compared to applicable provincial and federal guidelines. Typically, if samples exceed these guidelines, further sampling is recommended, including sampling biotic media such as animal tissue. However, difficulties may arise when basic assumptions are proved untrue, such as seen in this study. This study followed a similar tiered approach and assumed areas where concentrations in abiotic media which exceeded guidelines in previous studies would also contain biotic media with elevated contaminant concentrations. This was not always the case. There may have been several factors affecting contaminant levels and availability found in this study, such as total organic carbon, biological activity and grain size.

WL1 and WL2 were considered a priori severely impacted based on historical raw effluent discharges and Phase II Environmental Site Assessment results (GHD 2018a). However, WL5 (a priori considered moderately impacted) exceeded several low level and high-level guidelines for sediment and surface water and was significantly higher than most reference values for sediment and surface water concentrations. Previous studies sampled a neighbouring cove in Boat Harbour and reported sediment PEL guideline exceedances for metals and PCDD/PCDFs. Similarly, samples in the stabilization lagoon near WL3, which had several surface water guideline exceedances, reported sediment PEL exceedances (Hoffman et al. 2017a, 2019). Due to proximity of the studied wetlands to Boat Harbour, it is possible that Boat Harbour effluent has continued to contaminate these wetlands. Additionally, all wetlands experienced drying throughout the summer of 2018, which was reported as hotter and drier than previous years by the Government of Canada (2019). Wetland drying was particularly extreme in WL5 and REF1, where perimeter areas with $>30 \mathrm{~cm}$ of standing water were dry by season end. It is possible that water evaporation concentrated contaminants in WL5. For example, drying and reflooding in wetland sediments has been reported to increase metal contaminant mobility (Lau and Chu 1999). If yearly data is available to characterize hydrological patterns, it should be used to identify whether wetlands dry regularly.

Another factor influencing sediment metal concentrations is TOC (Table 2). TOC correlates positively with metal concentrations (Walker et al. 2015). TOC is a sediment toxicity modifying factor as metals have an affinity for organic matter (Remeikaite-Nikiene et al. 2018). TOC has been shown to increase with depth, as biodiversity and biomass decrease (Soto et al. 2016). TOC was not significantly correlated with PCDD/ PCDF, but this was likely the result of small sample sizes. However, in 2013 sediment samples within Boat Harbour were collected and tested for various COPC, including PCDD/PCDF (Russell 2015). The highest concentration of PCDD/PCDFs were mid-settling basin, as opposed to adjacent the ASB outfall. It was concluded that this was due to historic changes in PCDD/PCDF concentrations in effluent, spatially variable sediment deposition, and differences in the bottom profile of sampled locations (Russell 2015; Pictou Landing Native Women's Group 2016), which were comparable to results in this study, therefore highlighting the influence of TOC. 

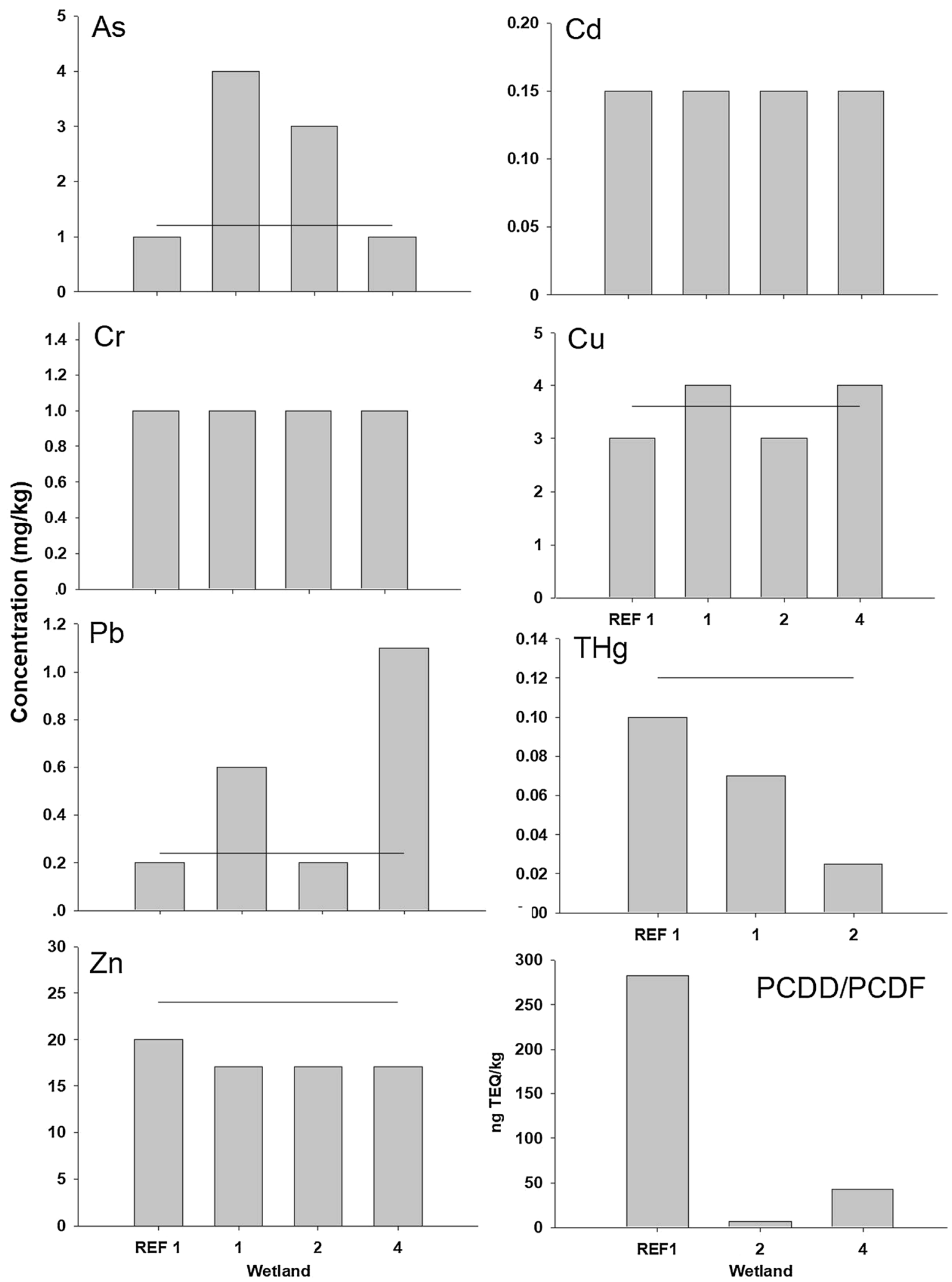
4 Fig. 6 Libellulidae tissue concentrations of 8 COPC. Solid line represents the REF concentration $+20 \%$, which the other concentrations are compared against

TOC can also explain high surface water concentrations, such as in WL3. WL3 was fairly shallow (water depth approximately $0.5-0.6 \mathrm{~m}$ ). Previous samples in the connected lagoon revealed sediment guideline exceedances (Hoffman et al. 2017a), but WL3 has a shallower surface water depth than those lagoon samples. With WL1 and WL2, it was shown that pelagic surface water samples with high TOC had higher sediment metal concentrations than littoral samples. With this context, it is likely that the pelagic lagoon samples would have higher sediment TOC concentrations, and thus higher contamination, than the littoral, low TOC wetlands. Given the affinity of TOC-rich sediments to metals and organic compounds (Kalbitz and Wennrich 1998), the low TOC concentrations can explain why metals and PCDD/PCDF remained in the water column rather than strongly partitioning to the sediment. If bulk of contaminants are not sequestered in sediments where they are less bioavailable, uptake by water-based organisms is more likely. Higher bioavailability should then be considered as a factor when determining remediation plans. However, this could not be tested as insufficient tissue for analysis was collected from WL3 for analysis. To help address the lack of tissue samples to determine metal contaminant bioavailability a concurrent study by Chaudhary et al. (2020b) used in situ diffusive gradient thin (DGT) films. DGTs were used to measure metal (loid), $\mathrm{THg}$ and $\mathrm{Me}-\mathrm{Hg}$ concentrations within $5 \mathrm{~cm}$ of the sediment/water interface in marine and freshwater sites (including wetlands) to help with site characterization. Bioavailable metal (loid) and $\mathrm{THg}$ concentrations were low and $\mathrm{Me}-\mathrm{Hg}$ concentrations were below detection levels across all sites. Results suggest that ecological risk to aquatic organisms was low (Chaudhary et al. 2020b). Low TOC in WL3 may be related to shallow depths increasing the effects of water currents and wind-induced wave action on sediment resuspension (Soto et al. 2016). As well, wetland vegetation, litter decomposition and climatic conditions can influence TOC accumulation (Kalbitz and Wennrich 1998). Bulk density, salinity and soil composition can cause different types of plant communities and primary production rates, which in turn influence organic carbon stores (Luo et al. 2014). The macrophyte community in WL3 was not assessed in this study, so the potential effect on TOC can only be speculated.

Grain size also impacts metal concentrations in sediment, as studies have shown finer-grained sediments result in higher metal concentrations (Horowitz 1986; Maslennikova et al. 2012; Soto et al. 2016). Finer-grained sediments have higher surface area to volume ratios and provide increased area for sorption of heavy metals. (Horowitz 1986; Lakhan et al 2003). GHD (2019) calculated grain size for consultant study samples taken in WL1 and WL2. The result of this analysis indicated sediment was generally composed of grain size less than $120 \mu \mathrm{m}$ (GHD 2019). Sediment in WL3, WL4, WL5, REF1 and REF2 were visually similar, so it is likely the substrate composition in these wetlands is comparable. Given the inverse correlation between grain size and metal concentrations, the fine-grain profile of the wetlands influenced the metal concentrations. Further analysis should compare grain size between the deep and shallow vertical water column wetland areas, as differences could explain the metal concentration variances observed in this study.

WL5 exceeds the conservative guidelines for surface water for $\mathrm{Cd}, \mathrm{Cr}$ and $\mathrm{Cu}$. Due to the conservative nature of these guidelines, exceedances may be of little ecological importance. However, WL5 was notably different than reference wetlands that are similar in type and location, as several contaminants

Table 2 Spearman rho correlation analysis between sediment contaminant concentrations and TOC values

\begin{tabular}{|c|c|c|c|c|c|c|c|c|}
\hline & $\begin{array}{l}\text { TOC and } \\
\text { As }\end{array}$ & $\begin{array}{l}\text { TOC and } \\
\text { Cd }\end{array}$ & $\begin{array}{l}\text { TOC and } \\
\mathrm{Cr}\end{array}$ & $\begin{array}{l}\text { TOC and } \\
\mathrm{Cu}\end{array}$ & $\begin{array}{l}\text { TOC and } \\
\mathrm{Pb}\end{array}$ & $\begin{array}{l}\text { TOC and } \\
\mathrm{Hg}\end{array}$ & $\begin{array}{l}\text { TOC and } \\
\mathrm{Zn}\end{array}$ & $\begin{array}{l}\text { TOC and PCDD/ } \\
\text { PCDF }\end{array}$ \\
\hline Correlation & 0.40 & $0.89 *$ & $0.73 *$ & $0.75^{*}$ & $0.89 *$ & $0.85^{*}$ & $0.79 *$ & 0.65 \\
\hline
\end{tabular}

Asterisk (*) represent $p<0.05$ 
were markedly higher than the reference wetlands. However, the intra-wetland variability made for large standard errors and significant differences were not detected. A greater number of samples would decrease the standard error.

Further, processes within wetlands, such as uptake, sequestration, decomposition and biodegradation, allow wetlands to effectively "self-clean" contaminants that are present in the system (Vymazal and Březinová 2016). This ability has been applied in natural and constructed wetlands for wastewater treatment purposes (Galbrand 2004). For example, burial of contaminants through natural deposition of cleaner sediments can reduce surface sediment concentrations over time (Magar and Wenning 2006). Assimilative capacity of wetlands to remove or reduce contaminants may also explain why WL1 and WL2 contained low concentrations of COPC in the shallow areas, as 46 years have passed since the raw effluent release, giving these natural processes time to be effective. In comparison, WL5 has been exposed to effluent more recently. Phragmites spp., commonly used in phytoremediation, accumulate heavy metals, which can then be removed from the wetland through harvesting efforts (Lesage et al. 2007). Other plants, including Typha spp., have also been used for their ability to reduce bacteria, organic chemicals and inorganic chemicals in wetlands (Ciria et al. 2005; Rani et al. 2011). Lower contaminant concentrations at the time of sampling may have been due to the presence of macrophytes, which could have taken up and incorporated contaminants into tissue during the summer months.

Odonata larvae have been used frequently in assessments of metal-contaminated wetlands. Generally, researchers have found larvae to have increased metal tissue concentrations in metal contaminated areas when compared to reference areas (Azam et al. 2015; Nasirian and Irvine 2017). Partitioning of contaminants to different areas of larvae tissue have been studied, as this could affect trophic transfer of contaminants. For example, Lavilla et al. (2010) found that $\mathrm{Cu}, \mathrm{Cd}$ and $\mathrm{Zn}$ associate with Odonate inner tissues, whereas As, Cr, iron (Fe), manganese ( $\mathrm{Mn})$, nickel $(\mathrm{Ni})$ and $\mathrm{Zn}$ associated with outer tissues. Similarly, $\mathrm{THg}$ and $\mathrm{MeHg}$ differential partitioning across Odonate body sections has been demonstrated (Buckland-Nicks 2011). LeBlanc (2019) determined Odonate casings accounted for $93 \%$ of As lost from the larval to adult stage. Although total body load was measured for this study as oppose to body parts, these studies highlight uptake and assimilation of contaminants into Odonate tissue. Given this, a stronger relationship between sediment concentrations and tissue concentrations was expected. However, the only significant relationships found was for $\mathrm{Pb}$ in sediment and tissue (Table 1). This could be due to metal contaminants sorbing to finer grained, higher organic sediment in deeper areas, whereas Libellulidae larvae were found in shallow water. Even in uniform depth wetlands (e.g. WL5), variation in sediment contamination was still present. Libellulidae larvae were collected from a larger area than sediment samples. Therefore, larvae could have been exposed to a variety of contaminant concentrations not well represented by discrete sediment sample locations.

In addition, several reference tissue samples displayed higher concentrations than the Boat Harbour Treatment Facility samples. For example, PCDD/ PCDF tissue concentrations for the reference wetland were 6.5 to 42 times higher than WL4 and WL2 respectively. Although this result was unexpected, PCDD/PCDF concentrations in REF1 exceeded ISQGs, and individually appear higher than WL2 and WL4 when an outlier in WL2-1 is removed (Fig. 5). Although REF1 resides on property that is not directly influenced by industries, improper waste disposal, wood and coal burning, and forest fires nearby could have increased the PCDD/PCDF concentrations in REF1 (Dyke et al 1997; Kanan and Samara 2018) and consequently influenced tissue concentrations. A nearby coal burning power plant emits various air pollutants, such as hydrochloric acid, sulphuric acid and mercury, and could have influenced these concentrations (NPRI 2018). In 2018, Pictou County experienced 23 wildfires, a majority of which occurred just prior to sampling and could have impacted these concentrations (Department of Lands and Forestry 2018). Wind rose simulations show wind direction in the area generally blows north-east (Hoffman et al. 2017b), and greater atmospheric deposition from these events may have occurred in REF1 than in the Boat Harbour Treatment Facility. Although Spearman rho correlation did not identify a relationship between sediment and tissue PCDD/ PCDF concentrations, this may be due to the limited sample size and not a lack of relationship. Additional samples should be taken to further explore this. 
THg concentration was higher in REF1 Libellulidae tissue than WL1 and WL2, even though sediment THg was higher in WL1 and WL2. LeBlanc (2019) showed emergent Odonata from Hg-contaminated wetlands can transport $\mathrm{Hg}$ out of the wetlands, since a significant amount of $\mathrm{Hg}$ is retained in adult Odonates from their larval stage. Odonata can travel outside of their natal area to search for higher habitat quality and mate selection (Crumrine et al. 2008). It is possible that the higher $\mathrm{THg}$ concentrations found in the REF tissue was the result of contamination from an outside source that was transported through parental adults. As well, MeHg can account for a high portion of THg (Buckland-Nicks et al. 2014) and since MeHg is highly bioaccumulative, it is also plausible that the Libellulidae larvae, obligate carnivores by nature, display high $\mathrm{THg}$ concentrations as the result of high $\mathrm{THg}$ or $\mathrm{MeHg}$ concentrations in their prey. Libellulidae prey on plankton and smaller invertebrates (Suhling et al. 2015). Phytoplankton and zooplankton have been shown to readily uptake and assimilate $\mathrm{MeHg}$, effectively introducing the contaminant into the food web (Stewart et al. 2008; Schartup et al. 2018). It is possible that the plankton within the reference area were either recently impacted by a $\mathrm{Hg}$ contamination source, or the plankton community composition and activity resulted in greater mercury uptake. For example, other factors, such as productivity and nutrient content, affect $\mathrm{MeHg}$ concentrations in marine plankton (Schartup et al. 2018). pH and selenium (Se) content also affect plankton $\mathrm{Hg}$ uptake, with acidic waters increasing uptake and Se providing a protective effect against uptake (Belzile et al. 2006; Yang et al. 2008; Le Faucheur et al. 2014). Selenium results were consistently under detection limits $(1.0 \mathrm{mg} / \mathrm{kg})$ for the tissue sampled from the wetlands but could have been present at low levels. For example, the Se compound selenite has protective qualities starting at $0.5 \mathrm{mg} / \mathrm{kg}$ (Yang et al. 2008). Due to undetectable concentrations, Se is unlikely to be a significant factor in the present study. As well, an inverse correlation occurs between algal abundance and $\mathrm{Hg}$ concentration in zooplankton through a process called "bloom dilution" (Pickhardt et al. 2002; Luengen and Flegal 2009). The reference site did not appear to have a high occurrence of algal blooms, which may have resulted in a higher $\mathrm{THg}$ concentration for zooplankton uptake and consequently Libellulidae uptake.
When comparing results to the GHD Human Health and Environmental Risk Assessment (2019), only WL1 and WL2 were considered, as those were included in the risk assessment (Table 3). There were a few notable differences, which reflect common risk assessment practices in identifying COPCs. Exceedances of PELs were more common in the GHD (2019) risk assessment and selection of COPC differed from this study. In this study, if a contaminant maximum concentration exceeded ISQG or PEL guidelines but was not significantly different from reference wetlands (NSDB), it was considered a probable contaminant of concern $(\mathrm{P})$. If a contaminant exceeded ISQG or PEL guidelines and was significantly different from the reference wetland (SDB), it was considered a contaminant of concern (Y). If the contaminant did not exceed guidelines and was NSDB, it was not considered a contaminant of concern (N) (Table 3).

For the risk assessment by GHD (2019), if a contaminant exceeded guidelines but was NSDB, it was not considered to be a contaminant of concern (N). If a contaminant exceeded guidelines and was SDB, it was considered a contaminant of concern (Y). Due to this difference in judgement, $\mathrm{Cd}$, $\mathrm{THg}$ and $\mathrm{Zn}$ were not considered to be contaminants of concern (N) for the consultant lead risk assessment but were considered probable contaminants of interest (P) for this study. Arsenic was considered a contaminant of concern for this study but was not identified as a contaminant of concern for GHD's assessment. Concentrations were similar between this study and the human health and environmental risk assessment, although the latter generally contained greater maximum concentrations. This may be the result of a greater number of samples as the risk assessment collected up to 42 samples per contaminant, whereas this study collected three. Surface water contaminant concentrations in this study were compared to those reported by GHD (2019), similar to the sediment comparison (Table 4). Differences in detectable metals in surface water samples between this study and GHD (2019) may be due to differences in sampling times. GHD (2019) samples were collected during the fall, whereas this study collected samples during the summer. Sampling methods were similar. Exceedances were found in the risk assessment for contaminants not analyzed as a part of this study, such as volatile organic compounds, semi-volatile organic 
Table 3 Comparison of sediment COPC decisions between the current study and GHD's HHERA (GHD 2019)

\begin{tabular}{|c|c|c|c|c|c|c|c|}
\hline \multirow[t]{2}{*}{ COPC } & \multicolumn{2}{|c|}{ CCME guideline } & \multicolumn{3}{|l|}{ Current study } & \multicolumn{2}{|c|}{ GHD (2019) } \\
\hline & $\begin{array}{l}\text { ISQG } \\
(\mathrm{mg} / \mathrm{kg})\end{array}$ & $\begin{array}{l}\text { PEL } \\
(\mathrm{mg} / \mathrm{kg})\end{array}$ & $\begin{array}{l}\text { COPC } \\
\text { decision }(\mathrm{N} / \\
\mathrm{P} / \mathrm{Y})\end{array}$ & $\begin{array}{l}\text { Rationale, (maximum } \\
\text { concentration }(\mathrm{mg} / \mathrm{kg}) \text { ) }\end{array}$ & $\begin{array}{l}\text { Mean } \\
\text { concentration } \\
(\mathrm{mg} / \mathrm{kg})\end{array}$ & $\begin{array}{l}\text { COPC } \\
\text { decision } \\
(\mathrm{N} / \mathrm{Y})\end{array}$ & $\begin{array}{l}\text { Rationale (maximum } \\
\text { concentration }(\mathrm{mg} / \mathrm{kg}) \text { ) }\end{array}$ \\
\hline As & 5.9 & 17 & $\mathrm{Y}$ & > ISQG SDB (13) & 8.8 & $\mathrm{~N}$ & $>$ PEL, NSDB (26) \\
\hline $\mathrm{Cd}$ & 0.6 & 3.5 & $\mathrm{P}$ & > PEL NSDB (4.8) & 2.26 & $\mathrm{~N}$ & $>$ PEL, NSDB (8.2) \\
\hline $\begin{array}{l}\mathrm{Cr} \\
\text { (total) }\end{array}$ & 37.3 & 90 & $\mathrm{P}$ & > PEL NSDB (105) & 43.3 & $\mathrm{Y}$ & $>$ PEL, SDB (170) \\
\hline $\mathrm{Cu}$ & 35.7 & 197 & $\mathrm{P}$ & > ISQG NSDB (66) & 43.7 & $\mathrm{~N}$ & > ISQG (69) \\
\hline $\mathrm{Pb}$ & 35 & 91.3 & $\mathrm{~N}$ & > ISQG NSDB (66) & 30.1 & $\mathrm{~N}$ & > ISQG (65) \\
\hline $\mathrm{THg}$ & 0.17 & 0.49 & $\mathrm{P}$ & > ISQG NSDB (0.84) & 0.25 & $\mathrm{~N}$ & > IQSG (2.1) \\
\hline $\mathrm{Zn}$ & 123 & 315 & $\mathrm{P}$ & $>$ PEL NSDB (361) & 250 & $\mathrm{~N}$ & $>$ PEL, NSDB (490) \\
\hline $\begin{array}{l}\text { PCDD/ } \\
\text { PCDF }\end{array}$ & $\begin{array}{l}0.85 \mathrm{ng} \\
\text { TEQ.kg }\end{array}$ & $\begin{array}{l}21.5 \mathrm{ng} / \\
\mathrm{kg}\end{array}$ & $\mathrm{P}$ & $\begin{array}{l}>\text { PEL NSDB (594 ng } \\
\text { TEQ/kg) }\end{array}$ & 200 & $\mathrm{Y}$ & $\begin{array}{l}>\text { PEL; SDB (918 ng } \\
\text { TEQ/kg) }\end{array}$ \\
\hline
\end{tabular}

$N S D B$ no significant difference from background levels, $S D B$ significant difference from background level

Table 4 Comparison of surface water COPC decisions between the current study and the HHERA

\begin{tabular}{|c|c|c|c|c|c|c|c|}
\hline \multirow[t]{2}{*}{$\mathrm{COPC}$} & \multicolumn{2}{|c|}{ CCME guideline } & \multicolumn{3}{|c|}{ Current study } & \multicolumn{2}{|c|}{ GHD (2019) } \\
\hline & $\begin{array}{l}\text { Short term } \\
(\mathrm{S} . \mathrm{T})(\mu \mathrm{g} / \\
\mathrm{L})\end{array}$ & $\begin{array}{l}\text { Long term } \\
(\mathrm{L} . \mathrm{T})(\mu \mathrm{g} / \\
\mathrm{L})\end{array}$ & $\begin{array}{l}\text { COPC } \\
\text { decision } \\
(\mathrm{N} / \mathrm{P} / \mathrm{Y})\end{array}$ & $\begin{array}{l}\text { Rationale, [maximum } \\
\text { concentration }(\mu \mathrm{g} / \mathrm{L})]\end{array}$ & $\begin{array}{l}\text { Mean } \\
\text { concentration } \\
(\mu \mathrm{g} / \mathrm{L})\end{array}$ & $\begin{array}{l}\text { COPC } \\
\text { decision } \\
(\mathrm{N} / \mathrm{Y})\end{array}$ & $\begin{array}{l}\text { Rationale (maximum } \\
\text { concentration }(\mu \mathrm{g} / \mathrm{L}))\end{array}$ \\
\hline As & - & 5 & $\mathrm{~N}$ & < L.T (N.D.) & $<2.0$ & $\mathrm{~N}$ & < L.T (N.D.) \\
\hline $\mathrm{Cd}$ & 1.0 & 0.09 & $\mathrm{~N}$ & < L.T (N.D.) & $<0.09$ & $\mathrm{~N}$ & < L.T (N.D.) \\
\hline $\begin{array}{l}\mathrm{Cr} \\
\quad(\mathrm{Cr}(\mathrm{VI})) / \\
\mathrm{Cr}(\mathrm{III}))\end{array}$ & - & $1,8.9$ & $\mathrm{P}$ & $\begin{array}{l}=\text { Cr(VI) L.T (1.0), } \\
\text { NSDB }\end{array}$ & $0.60 *$ & $\mathrm{~N}$ & < L.T (N.D.) \\
\hline $\mathrm{Cu}$ & - & 2 & $\mathrm{P}$ & $>$ L.T NSDB (3) & $0.92 *$ & $\mathrm{~N}$ & < L.T (N.D.) \\
\hline $\mathrm{Pb}$ & - & 1 & $\mathrm{P}$ & $>$ L.T, NSDB (1.2) & $0.41 *$ & $\mathrm{~N}$ & < L.T (N.D.) \\
\hline $\mathrm{THg}$ & - & 0.026 & $\mathrm{~N}$ & < L.T (N.D.) & $<0.026$ & $\mathrm{~N}$ & < L.T (N.D.) \\
\hline $\mathrm{Zn}$ & 37 & 7.0 & $\mathrm{~N}$ & $>$ L.T (14) & $5.0^{*}$ & $\mathrm{~N}$ & < L.T (N.D.) \\
\hline
\end{tabular}

Asterisks (*) identify instances where a portion of samples had detectable concentrations and other samples had nondetectable concentrations. In these cases, $1 / 2 \mathrm{DLs}$ were used for concentrations below DL

compounds, and polycyclic aromatic hydrocarbons. On the other hand, this study identified sediment exceedances $(\mathrm{Cd}, \mathrm{Cu}, \mathrm{Pb}$ and $\mathrm{Zn})$ in wetlands that were not studied in the consultant lead risk assessment, specifically WL5. Similarly, this study identified surface water exceedances that were not studied in the risk assessment, specifically in WL3 and WL5. This comparison highlights the importance of comparing contamination studies to other studies outside of academia, as it can highlight issues that cannot be identified by strictly comparing to guidelines.

There have been many previous studies focused solely on contamination present in the lagoon. Contaminant ranges in lagoon sediment (Hoffman et al. 2017a) was similar to or higher than the contamination levels in the wetlands analyzed for this study. These studies were completed over a 13-year time period and highlight the different partitioning and accumulation of contaminants in various areas of the Boat Harbour 
Treatment Facility. Similarities and differences between the Human Health and Environmental Risk Assessment and this study highlight the value of incorporating scientific studies into consultant-lead projects, as they can complement the lines of evidence and help inform remedial decisions. Both this study and the Human Health and Environmental Risk Assessment recommended further sampling and delineation. Further sampling of wetland media and additional Boat Harbour Treatment Facility wetlands could increase understanding of the extent of the contamination, as well as provide further understanding of the impact range with different wetland types and sizes. Sampling should also occur during and after the Boat Harbour Treatment Facility remediation as part of an Environmental Effects Monitoring program to assess the effectiveness of remediation and should include a suite of multimedia monitoring (Walker 2014). As well, additional sampling equipment, such as an invertebrate activity trap, can be utilized to collect more Libellulidae tissue increasing the strength of future statistical analysis.

Although there were several guideline exceedances in this study, concentrations were lower than other contaminated wetlands in literature. For example, LeBlanc (2019) studied mine-contaminated wetlands in Nova Scotia, and found sediments contained $\mathrm{Hg}$ concentrations of $92.5 \pm 55.0 \mathrm{mg} / \mathrm{kg}$, which are noticeably higher than the concentrations found in this study. During a risk assessment at the Millbrook Superfund Site in Montana, the average arsenic concentration was $45.3 \mathrm{mg} / \mathrm{kg}$, the average copper concentration was $464.7 \mathrm{mg} / \mathrm{kg}$ and the average zinc concentration was $1426.2 \mathrm{mg} / \mathrm{kg}$, all of which are higher than this concentrations in this study (Pascoe et al. 1996). This study highlights that comparing contaminant concentrations to federal or provincial guidelines does not fully reflect the level of ecological impact in a wetland ecosystem. There are many factors, such as TOC, grain size, organism mobility, that can affect contaminant concentrations and contaminant bioavailability.

\section{Conclusion}

This study highlights the importance of considering other environmental factors rather only comparing environmental chemical concentrations to provincial and federal guidelines. Factors such as TOC, grain size and biological activity can play and important role in affecting contaminant bioavailability in wetland sediment and surface water. Wetlands (specifically WL3 and WL5) expressed high contaminant concentrations in sediment and surface water, likely due to nearby Boat Harbour Treatment Facility lagoon exceedances and recent effluent discharges. Although wetlands outside the study area yielded some high contaminant concentrations, guideline exceedances in wetlands adjacent to Boat Harbour should be carefully considered during planning of restoration efforts. Although some limited in situ active remediation is likely required in deep areas of wetlands historically exposed to effluent, natural attenuation is recommended. Natural attenuation and monitoring is recommended as a feasible remediation option for shallow wetland areas of WL1 and WL2. Remediation using monitored natural recovery will allow natural processes, such as burial, sorption, and biological transformation, to contain, immobilize and attenuate contaminant concentrations. Prior to remediation, additional sampling within the study wetlands adjacent to the Boat Harbour Treatment Facility should be undertaken to better understand the magnitude and volume of sediments requiring treatment.

Acknowledgements This study was funded by Nova Scotia Lands. We thank Dr. Rob Jamieson, Dr. Ian Spooner and the Community Based Environmental Monitoring Network for use of field equipment. We gratefully acknowledge Pictou Landing First Nation and local landowners for access to wetlands surrounding A'se' $\mathrm{K}$, as well as reference wetlands.

Funding This research was funded by Nova Scotia Lands.

Open Access This article is licensed under a Creative Commons Attribution 4.0 International License, which permits use, sharing, adaptation, distribution and reproduction in any medium or format, as long as you give appropriate credit to the original author(s) and the source, provide a link to the Creative Commons licence, and indicate if changes were made. The images or other third party material in this article are included in the article's Creative Commons licence, unless indicated otherwise in a credit line to the material. If material is not included in the article's Creative Commons licence and your intended use is not permitted by statutory regulation or exceeds the permitted use, you will need to obtain permission directly from the copyright holder. To view a copy of this licence, visit http://creativecommons.org/licenses/by/4.0/. 


\section{References}

Alimohammadi M, Tackley H, Lake C, Spooner I, Walker TR, Jamieson RC, Gan C, Bossy K (2019) Effects of different sediment dewatering technique on subsequent particle sizes in industrial derived effluent. Can J Civ Eng. https:// doi.org/10.1139/cjce-2019-0269

Alimohammadi M, Tackley H, Holmes B, Davidson K, Lake CB, Spooner IS, Jamieson RC, Walker TR (2020) Characterizing sediment physical property variability for bench scale dewatering purposes. Environ Geotech. https://doi. org/10.1680/jenge. 19.00214

Armellin A, Baird D, Curry C, Glozier N, Martens A, McIvor E (2017) Cabin Wetland Macroinvertebrate Protocol. Prepared by CABIN Wetland Subcommittee, pp 1-63. Last retrieved on October 20, 2020 from http://publications.gc. ca/collections/collection_2019/eccc/CW66-571-2019eng.pdf

Azam I, Afsheen S, Zia A, Javed M, Saeed R, Sarwar MK, Munir B (2015) Evaluating insects as bioindicators of heavy metal contamination and accumulation near industrial area of Gujrat, Pakistan. Hindawi Publishing Corporation, London, p 2015

Batzer D, Rader R, Wissinger S (1999) Invertebrates in freshwater wetlands of North America. Wiley, New York

Belzile N, Chen Y-W, Gunn JM, Tong J, Alarie Y, Delonchamp T, Lang C-Y (2006) The effect of selenium on mercury assimilation by freshwater organisms. Can J Fish Aquat Sci 63(1): $1-10$

Boat Harbour Act (2015) An act respecting the cessation of the use of the boat harbour effluent treatment facility for the reception and treatment of effluent from the Northern Pulp Mill. Government of Nova Scotia. Retrieved on September 20, 2017 from https://nslegislature.ca/legc/bills/62nd_2nd/ 1st_read/b089.htm

Buckland-Nicks AH (2011) Mercury bioaccumulation in dragonflies (Odonata: Anisoptera) from two lakes in Kejimkujik National Park, Nova Scotia

Buckland-Nicks A, Hillier KN, Avery T, O’Driscoll N (2014) Mercury bioaccumulation in dragonflies (Odonata: Anisoptera): examination of life stages and body regions. Environ Toxicol Chem 33(9):2047-2054

Center of Expertise in Environmental Analysis of Quebec (2013) Determination of phenolic compounnds: assay by Gas Chromatography coupled to a mass spectrometer after derivation with acetic ahydride. MY. 400-Phe 1.0. Revision 3.0. Ministry of Sustainable Development, Environment, Wildlife and Parks of Quebec, 1-20

Centre of Expertise in Environmental Analysis of Quebec (2014) Determination of total organic carbons in solids: Assay by titration, MA. 405-C 1.1. Rev. 1, Ministry of Sustainable Development, Environment and the Fight Against Climate Change, 1-9

Chaudhary M, Walker TR, Willis R, Oakes K (2020a) Baseline characterization of sediments and marine biota near industrial effluent discharge in Northumberland Strait, Nova Scotia, Canada. Mar Pollut Bull 157:111372

Chaudhary M, Quanz M, Williams J, Maltby E, Oakes K, Spooner IS, Walker TR (2020b) Assessment of metal(loid) concentrations using diffusive gradient thin (DGT) films in marine, freshwater and wetland aquatic ecosystems impacted by industrial effluents. Case Stud Chem Environ Eng 2:100041

Ciria MP, Solano ML, Soriano P (2005) Role of macrophyte Typha latifolia in a constructed wetland for wastewater treatment and assessment of its potential as a biomass fuel. Biosyst Eng 92(4):535-544. https://doi.org/10.1016/j. biosystemseng.2005.08.007

Canadian Council of Ministers of the Environment (CCME) (2019) Canadian Environmental Quality Guidelines. Retrieved on March 20, 2018 from https://www.ccme.ca/ en/resources/canadian_environmental_quality_guidelines/

CCME (2001). Canadian quality guidelines for the protection of aquatic life-Polychlorinated Dibenzo- p-Dioxins and Polychlorinated Dibenzofurans (PCDD/Fs). Canadian Environmental Quality Guidelines. http://st-ts.ccme.ca/en/ index.html. Accessed 30 Jun 2019

CCME (2003) Canadian water quality guidelines for the protection of aquatic life: mercury. Canadian Environmental Quality Guidelines. CCME, Winnipeg

CCME (2018) Canadian water quality guidelines for the protection of aquatic life: zinc. Canadian Environmental Quality Guidelines. CCME, Winnipeg, pp 1-13

Crumrine P, Switzer P, Crowley P (2008) Structure and dynamics of odonate communities: accessing habitat, responding to risk, and enabling reproduction. In: Alex C-A (ed) Dragonflies and damselflies: model organisms for ecological and evolutionary research. Oxford University Press, Oxford, pp 21-38

De Klerk LP, De Klerk AR, Wepener V (2013) An assessment of mercury contamination and the relationship between environmental variables and mercury concentrations in a seasonal wetland. Water Air Soil Pollut 224(5):1547

Department of Lands and Forestry (2018) Nova Scotia Wildfire Statistics-2018. Retrieved on March 15, 2019 from https://novascotia.ca/natr/forestprotection/wildfire/stats/ 2018gen.asp

Dillon Consulting Limited (2019) Replacement effluent treatment facility, environmental assessment: appendix $\mathrm{J}$ cycle 7 EEM results. Dillon Consulting Limited, Calgary

Dyke P, Coleman P, James R (1997) Dioxins in ambient air, bonfire night 1994. Chemosphere 34(5-7):1191-1201

EC, \& OMOE (2008) Canada-Ontario decision-making framework for assessment of Great Lakes contaminated sediment. Retrieved on September 30, 2018 from http://www. lssu.edu/bpac/Materials/Canada-OntarioDecisionMakingFramework.pdf

Eichinger L, Walker TR (2020) Review of remedial options for the Boat Harbour remediation project in Nova Scotia Canada. Remediat J. https://doi.org/10.1002/rem.21670

Fisheries Act (1985) Fisheries Act c. F-14, s.1

Fletcher DE, Lindell AH, Stillings GK, Blas SA, Mcarthur V (2017) Trace element accumulation in lotic dragonfly nymphs: genus matters. PLoS ONE 12(2):1-27

Galbrand C (2004) Naturalized treatment wetlands for contaminant removal: a case study of the Burnside Engineered Wetland for treatment of landfill leachate. (Master of Environmental Studies thesis). Dalhousie University.

GHD (2018a) Phase 2 environmental site assessment: boat harbour remediation, planning and design, Pictou County Nova Scotia. Nova Scotia Land Inc., Halifax NS 
GHD (2018b) Remedial option decisions document boat harbour remediation planning and design (Project). Nova Scotia Land Inc., Halifax, NS

GHD (2019) Quantitative human health and ecological risk assessment. Nova Scotia Land Inc, Halifax, NS

Government of Canada (2019) Daily Maximum Temperature for June, July, September. Retrieved on October 20, 2020 from http://climate.weather.gc.ca/climate_data/generate_ chart_e.html?StationID=8990\&timeframe $=2 \&$ StartYear= $1840 \&$ EndYear $=2019 \&$ Day $=5 \&$ Year $=2018 \&$ Month $=$ $8 \&$ type $=$ line $\&$ Meas $T y p e I D=$ maxtemp

Government of Canada (2020) Boat Harbour remediation project. Retrieved on October 20, 2020 from https://www. ceaa-acee.gc.ca/050/evaluations/proj/80164

Hoffman E, Bernier M, Blotnicky B, Golden PG, Janes J, Kader A, Kovacs-Da Costa R, Pettipas S, Vermeulen S, Walker TR (2015) Assessment of public perception and environmental compliance at a pulp and paper facility: a Canadian case study. Environ Monit Assess 187:1-13

Hoffman E, Lyons J, Boxall J, Robertson C, Lake CB, Walker TR (2017a) Spatiotemporal assessment (quarter century) of pulp mill metal(loid) contaminated sediment to inform remediation decisions. Environ Monit Assess 189(6):257

Hoffman E, Guernsey JR, Walker TR, Kim JS, Sherren K, Andreou P (2017b) Pilot study investigating ambient air toxics emissions near a Canadian kraft pulp and paper facility in Pictou County, Nova Scotia. Environ Sci Pollut Res 24:20685-20698

Hoffman E, Alimohammadi M, Lyons J, Davis E, Walker TR (2019) Characterization and spatial distribution of organiccontaminanted sediment derived from historical industrial effluents. Environ Monit Assess 191:590

Horowitz AJ (1986) A primer on trace metal-sediment chemistry. US Geological Survey Water-Supply Paper, Washington, DC, p 2277

Jeremiason JD, Reiser TK, Weitz RA, Berndt ME, Aiken GR (2016) Aeshnid dragonfly larvae as bioindicators of methylmercury contamination in aquatic systems impacted by elevated sulfate loading. Ecotoxicology 25(3):456-468

Jones K, Lanthier Y, van der Voet P, van Valkengoed E, Taylor D, Fernández-Prieto D (2009) Monitoring and assessment of wetlands using earth observation: the globwetland project. J Environ Manage 90(7):2154-2169

Kalbitz K, Wennrich R (1998) Mobilization of heavy metals and arsenic in polluted wetland soils and its dependence on dissolved organic matter. Sci Total Environ 209:27-39

Kanan S, Samara F (2018) Dioxins and furans: a review from chemical and environmental perspectives. Trends Environ Anal Chem 17:1-13

Lakhan VC, Cabana K, LaValle PD (2003) Relationship between grain size and heavy metals in sediments from beaches along the coast of Guyana. J Coast Res 19(3):600-608

Lau S, Chu L (1999) Contaminant release from sediments in a coastal wetland. Water Res 33(4):909-918

Lavilla I, Rodríguez-Liñares G, Garrido J, Bendicho C (2010) A biogeochemical approach to understanding the accumulation patterns of trace elements in three species of dragonfly larvae: evaluation as biomonitors. J Environ Monit 12(3):724-730
LeBlanc M (2019) Bioaccumulation and transfer of mercury and arsenic in aquatic invertebrates and emergent insects at historic gold mine tailings sites of Nova Scotia. (Master of Science Thesis). Saint Mary's University, Halifax, Nova Scotia.

Le Faucheur S, Campbell PGC, Fortin C, Slaveykova VI (2014) Interactions between mercury and phytoplankton: speciation, bioavailability, and internal handling. Environ Toxicol Chem 33(6):1211-1224

Lesage E, Rousseau DPL, Meers E, Tack FMG, De Pauw N (2007) Accumulation of metals in a horizontal subsurface flow constructed wetland treating domestic wastewater in Flanders, Belgium. Sci Total Environ 380(1-3):102-115

Luengen AC, Flegal AR (2009) Role of phytoplankton in mercury cycling in the San Francisco Bay estuary. Limnol Oceanogr 54(1):23-40

Luo X, Wang L, Dun M, Yang J, Wang Z (2014) The accumulation and seasonal dynamic of the soil organic carbon in wetland of the Yellow River Estuary, China. J Chem. https://doi.org/10.1155/2014/408923

Magar VS, Wenning RJ (2006) The role of monitored natural recovery in sediment remediation. Integr Environ Assess Manage 2(1):66-74

Maslennikova S, Larina N, Larin S (2012) The effect of sediment grain size on heavy metal content. Lakes Reserv Ponds 6(1):43-54

Minitab Inc. (2017) Minitab 18.1. [Computer software]. Minitab Inc., State College, PA

Moore P (2008) Wetlands, Revised. Facts on File Inc., New York

Munkittrick K, McMaster M, Servos M (2013) Detection of reproductive impacts of effluents from pulp and paper mills: shifts in issues and potential causes. Environ Toxicol Chem 32(4):729-731

Nasirian H, Irvine K (2017) Odonata larvae as a bioindicator of metal contamination in aquatic environments: application to ecologically important wetlands in Iran. Environ Monit Assess 189(436):1-18

Nova Scotia Department of Natural Resources (2015) Provincial landscape viewer. Retrieved on March 15, 2018 from https://nsgi.novascotia.ca/plv/

Nova Scotia Environment (2013) Ministerial Protocols: Notification of Contamination Protocols. Retrieved on February 15, 2018 from https://novascotia.ca/nse/contaminatedsites/ protocols.asp

Nova Scotia Minister for the Environment (2013) Ministerial protocols: tier 1. Retrieved on February 15, 2018 from https://novascotia.ca/nse/contaminatedsites/protocols.asp

NPRI (2018) Facility and substance information: Nova Scotia power incorporated-trenton generating station 2017. Retrieved on May 20, 2019 from https://pollution-waste. canada.ca/national-release-inventory/archives/index. $\mathrm{cfm} ? \mathrm{do}=$ facility_substance_summary\&lang=en\&opt_ npri_id=0000003996\&opt_report_year $=2017$

Pascoe G, Blacher R, Linder G (1996) Food chain analysis of exposures and risks to wildlife at a metals-contaminated wetland. Environ Contam Toxicol 30:306-318

Pickhardt PC, Folt CL, Chen CY, Klaue B, Blum JD (2002) Algal blooms reduce the uptake of toxic methylmercury in freshwater food webs. Proc Natl Acad Sci USA 
99(7):4419-4423. 072531099

Pictou Landing Native Women's Group (c/o Shelia Francis, past president) Castleden H, Lewis D, Jamieson R, Gibson M, Rainham D, Russell R, Martin D, Hart C (2016) "Our ancestors are in our land, water, and air": a two-eyed seeing approach to researching environmental health concerns with Pictou Landing First Nation Final Report, (October)

Pokhrel D, Viraraghavan T (2004) Treatment of pulp and paper mill wastewater-a review. Sci Total Environ 333:37-58

Pulp and Paper Effluent Regulations (PPER) (1992) Pulp and Paper Effluent Regulations. Fisheries Act SQR/92-69. P.C. 1992-961

Province of Nova Scotia (2018) Boat harbour remediationabout the project. Retrieved on October 20, 2020 from https://novascotia.ca/boatharbour/about.asp

Province of Nova Scotia (2020) Boat harbour remediation project. Retrieved on October 20, 2020 from https:// novascotia.ca/boatharbour/

Quanz M, Willis R, Burr D, Recoskie R, Walker TR (2020) Aquatic ecological risk assessment frameworks in Canada: a case study using a single framework in South Baymouth, Ontario, Canada. Environ Monit Assess 192(8):530

Roach B, Walker TR (2017) Aquatic monitoring programs conducted during environmental impact assessments in Canada: preliminary assessment before and after weakened environmental regulation. Environ Monit Assess 189(3):109

Rani N, Maheshwari RC, Kumar V, Vijay VK (2011) Purification of pulp and paper mill effluent through Typha and Canna using constructed wetlands technology. J Water Reuse Desalin 1(4):237-242

Remeikaitè-Nikienè N, Garnaga-Budrè G, Lujanienè G, Jokšas K, Stankevičius A, Malejevas V, Barisevičiūtė R (2018) Distribution of metals and extent of contamination in sediments from the south-eastern Baltic Sea (Lithuanian zone). Oceanologia 60:193-206

Romo J, Chaudhary M, Walker TR (2019) Baseline assessment of contaminants in marine biota prior to remediation of industrial effluent impacted sediments in a former tidal estuary in Nova Scotia, Canada. Mar Pollut Bull 145:641-648

Russell R (2015) Sediment and Plankton Sampling for PCBs, Pesticides, Chlorophenols, Polybrominated Diphenyl Ethers, and Polychlorinated Dibenzodioxins and Furans. Retrieved on October 1, 2017 from http://heclab.com/wpcontent/uploads/2019/06/PLFNReport2016.pdf

Schartup AT, Qureshi A, Dassuncao C, Thackray CP, Harding G, Sunderland EM (2018) A model for methylmercury uptake and trophic transfer by marine plankton. Environ Sci Technol 52(2):654-662

Soto E, Quiroga E, Ganga B, Alarcón G (2016) Influence of organic matter inputs and grain size on soft-bottom macrobenthic biodiversity in the upwelling ecosystem of central Chile. Mar Biodivers 47(2):433-450

Standard Methods for the Examination of Water and Wastewater (2017a) 3125 Metals by Inductively Coupled PlasmaMass Spectrometry. Retrieved on April 20, 2019 from https://www.standardmethods.org/doi/10.2105/smww. 2882.048
Standard Methods for the Examination of Water and Wastewater (2017b) 3112 Metals by cold-vapor atomic absorption spectrometry. Retrieved on April 20, 2019 from https:// www.standardmethods.org/doi/full/10.2105/SMWW. 2882.044

Standard Methods for the Examination of Water and Wastewater $(2017$ c) 3030 Preliminary treatment of samples. Stewart, A.R., Saiki, M.K., Kuwabara, J.S., Alpers, C.N., Marvin-Di Pasquale, M., Krabbenhoft, D.P. (2008). Influence of plankton mercury dynamics and trophic pathways on mercury concentrations of top predator fish of a miningimpacted reservoir. Can J Fish Aquat Sci 65:2351-2366

Stewart A, Saiki M, Kuwabara J, Alpers C, Marvin-DiPasquale M, Krabbenhoft D (2008) Influence of plantkon mercury dynamics and trophic pathways on mercury concentrations of top predator fish of a mining-impacted reservoir. Can J Fish Aquat Sci 65:2351-2366

Suhling F, Sahlen G, Gorb S, Kalkman V, Dijkstra K-D, van Tol J (2015) Order odonata. In: Thorp JH, Rogers DC (eds) Thorp and Covich's freshwater invertebrates, 4th edn. Academic Press, Cambridge, pp 893-932

Tackley HA, Lake CB, Alimohammadi M (2020) Examining metal migration through geotextiles during dewatering. Geotext Geomembr. https://doi.org/10.1016/j.geotexmem. 2020.09.002

Toczylowska-Maminska R (2017) Limits and perspectives of pulp and paper industry wastewater treatment-a review. Renew Sustain Energy Rev 78:764-772

Tollett V, Benvenutti E, Deer L, Rice T (2009) Differential toxicity to $\mathrm{Cd}, \mathrm{Pb}$, and $\mathrm{Cu}$ in Dragonfly Larvae (Insecta:Odonata). Environ Contam Toxicol 56:77-84

USEPA. n.d. 245.5 - Mercury in soil/sediment: manual cold vapor. Retrieved on April 20, 2019 from http://www. brooksrandinc.com/content/uploads/2015/10/245_5Mercury-In-Sediment-Manual-Cold-Vapor.pdf

USEPA (1991) Mercury in tissue by cold vapor (CV/AAS). USEPA, Washington, DC

USEPA (1994a) Determination of trace elements in waters and wastes by inductively coupled plasma-mass spectrometry. Stand Methods Exam Water Wastewater 4:57

USEPA (1994b) Method 1613 tetra- through octa-chlorinated dioxins and furans by isotope dilution HRGC/HRMS October 1994. U.S. Environmental Protection Agency Office of Water Engineering and Analysis Division, Washington, DC

USEPA (1996) Acid digestion of sediments, sludges and soils. Office of Water, U.S Environmental Protection Agency, Washington DC

USEPA (1998) Inductively coupled plasma- mass spectrometry, vol 1. Office of Water, U.S. Environmental Protection Agency, Washington DC, pp 1-21

Vymazal J, Březinová T (2016) Accumulation of heavy metals in aboveground biomass of Phragmites australis in horizontal flow constructed wetlands for wastewater treatment: a review. Chem Eng J 290:232-242

Walker TR (2014) Environmental effects monitoring in Sydney Harbour during remediation of one of Canada's most polluted sites: a review and lessons learned. Remediat J 24(3):101-108

Walker TR, Willis R, Gray T, MacLean B, McMillan S, Leroy M, Appleton R, Wambolt N, Smith M (2015) Ecological 
risk assessment of sediments in Sydney Harbour, Nova Scotia, Canada. Soil Sediment Contam 24(5):471-493

WSP (2018) Boat Harbour remediation planning and design: wetland baseline review. WSP, Montreal

Yang D-Y, Chen Y-W, Gunn JM, Belzile N (2008) Selenium and mercury in organisms: interactions and mechanisms. Environ Rev 16:71-92

Yap B, Sim C (2011) Comparisons of various types of normality tests. J Stat Comput Simul 18(12):2141-2155
Publisher's Note Springer Nature remains neutral with regard to jurisdictional claims in published maps and institutional affiliations. 